\title{
EXPANSÃO URBANA DE SÃO MIGUEL/RN: ANÁLISE NO RECORTE TEMPORAL DE 2000 A 2017
}

\section{outoranda pelo Programa de Pós-Graduação em Engenharia Civil e Ambiental (PPG Programa de Pós-Graduação em Planejamento e Dinâmicas Territoriais no Semiárido (PLANDITES/UERN) danielafreitas1218@gmail.com} Professor da Universidade Federal Rural do Semi-Árido (UFERSA) e do Programa de Pós-Graduação em Planejamento e Dinâmicas Territoriais no Semiárido (PLANDITES/UERN) almir.mariano@ufersa.edu.br

Francisco do O' de Lima Júnior Professor da Universidade Regional do Cariri (URCA), do Programa de Pós-Graduação em Planejamento e Dinâmicas Territoriais no Semiárido (PLANDITES/UERN) e do Programa de Pós-Graduação em Economia Regional e Urbana (PPGERU/URCA) lima.junior@urca.br

José Henrique Maciel de Queiroz Mestrando pelo Programa de Pós-Graduação em Planejamento e Dinâmicas Territoriais no Semiárido (PLANDITES/UERN) henrique.jhmq@hotmail.com

\begin{abstract}
RESUMO
O crescimento urbano brasileiro ocorreu mais intensivamente a partir do século $X X$ motivado especialmente pela industrialização e, a consequente migração do campesinato, isto é, foi a influência capitalista que consolidou a inversão urbano-rural que o país vivenciou a partir da década de 1970. O objetivo deste trabalho é analisar a expansão urbana do município São Miguel/RN mediante as dinâmicas territoriais a ele associadas. Para tanto, foram estudados dados sobre a população, economia, instrumentos de ordenamento territorial e loteamentos deste município no período de 2000 a 2017, obtidos por meio da coleta documental digital e em órgãos municipais; e de entrevistas com prefeito municipal, historiador e colunista, chefe do departamento de fiscalização de obras e com moradores de São Miguel/RN. Constatou-se que a expansão urbana recente da cidade de São Miguel/RN teve a influência de dinâmicas sociodemográficas, do crescimento do setor terciário, dos parcelamentos do solo urbano e dos direcionamentos existentes em legislação municipal.
\end{abstract}

Palavras-chave: Crescimento urbano. Ordenamento territorial. Instrumentos legais urbanos. Especulação imobiliária.

\section{URBAN EXPANSION OF SÃO MIGUEL/RN CITY: ANALISY OF THE TEMPORARY CUTTING FROM 2000 TO 2017}

\begin{abstract}
The Brazilian urban growth occurred more intensively from the twentieth century, motivated especially by industrialization and the consequent migration of the peasantry, that is, it was the capitalist influence that consolidated the urban-rural inversion that the country experienced since the 1970's. The objective of this work is to analyze the urban expansion of the municipality of São Miguel/RN through the territorial dynamics associated with it. For that, data on the population, economy, instruments of territorial planning and subdivisions of this municipality were studied during the period from 2000 to 2017, obtained through the digital documentary collection and in municipal organs; and of interviews with city mayor, historian and columnist, head of the department of construction supervision, and residents of city São Miguel/RN. It was verified that the recent urban expansion of the city of São Miguel/RN was influenced by sociodemographic dynamics, growth of the tertiary sector, urban land subdivisions and existing directives in municipal legislation.
\end{abstract}

Keywords: Urban growth. Spatial planning. Urban legal instruments. Real estate speculation. 


\section{INTRODUÇÃO}

A configuração urbano-rural do Brasil foi modificada mais significativamente no século $X X$, impulsionada pelas "alternativas" sugeridas pela industrialização, que dispensou mão de obra do campo e tornou impotentes os produtores de pequeno porte, provocando o superpovoamento e a aglomeração de espaços divididos.

Neste contexto, a maioria das cidades são divididas, fragmentadas e conflituosas. A globalização e a guinada em direção ao neoliberalismo expandiram as desigualdades sociais, resultando as formas espaciais urbanas em "fragmentos fortificados", isto é, as cidades do capitalismo são divididas entre as elites financeiras e as grandes porções de trabalhadores de baixa renda (HARVEY, 2013).

O Brasil teve sua urbanização e industrialização tardia a partir do século $X X$, com taxas de crescimento elevadas entre os anos de 1940 e 1970, o que associado à ausência de mercado residencial formal e políticas públicas urbanas, desencadeou um excesso de mão de obra farta e barata e uma desigualdade social configurada por espaços hegemônicos e restritivos (MARICATO; COLOSSO; COMARÚ, 2018).

As noções de urbanização são geralmente fundamentadas na análise de grandes cidades, porém, as cidades pequenas são intrínsecas a este fenômeno e a globalização e suas determinações afetam e têm iserção nestas e em cidades médias (TERFA et al., 2020). As pessoas vivem cada vez mais em cidades pequenas e médias, o que gera uma densidade habitacional e uma urbanização prolongada nestes locais, no entanto, a discussão de urbanização de cidades pequenas não é realizada com frequência (FAHMI et al., 2014).

Neste sentido, a rede urbana instaurada no Brasil é composta, em sua maior parte, por cidades de até 100.000 habitantes. Segundo Fernandes (2018), há grupos de pesquisadores que defendem que, em termos de população, as cidades pequenas são aquelas que concentram até 20.000 habitantes; outros até 50.000 habitantes; e o Instituto Brasileiro de Geografia e Estatística (IBGE) até 100.000 habitantes; sendo que no menor número (até 20.000 habitantes), $77 \%$ das cidades são enquadradas como de pequeno porte no Brasil.

Assim, as cidades pequenas têm importante contribuição para o urbano brasileiro, uma vez que a maioria dos seus municípios é constituída por este tipo de cidade, onde vive uma população maior do que a de muitos países europeus; entretanto, o tema de cidades pequenas é pouco explorado pelos meios de divulgação acadêmicos (SPOSITO e JURADO DA SILVA, 2013). Fernandes e Correia (2018) elencam que mesmo que tenha havido um aumento do número de estudos de cidades pequenas nos últimos dez anos, este ainda não é expressivo. Neves e Faria (2020) afirmam que muitas vezes as cidades pequenas são relegadas aos estudos para que cidades médias, grandes e metrópoles sejam adotadas como objeto de debate.

Desse modo, as cidades pequenas carecem de pesquisas que mostrem sua configuração urbana. Neste quadro, cita-se a cidade de São Miguel/RN, uma cidade do interior do Estado do Rio Grande do Norte, de pequeno porte ao considerar-se o quesito população, mas que exerce influência sobre outros municípios, justificando a importância da realização de um estudo que discuta suas características.

Dados da Pesquisa Regiões de Influência das Cidades (REGIC), que apresentam a hierarquia das cidades de acordo com suas centralidades, dos anos de 1972, 1987 e 2007 mostram que em 1972 São Miguel/RN influenciava a cidade de Coronel João Pessoa/RN; em 1987 exercia influência sobre as cidades de Coronel João Pessoa/RN e Pereiro/CE; em 2007 polarizava as cidades de Coronel João Pessoa/RN e Venha-Ver/RN. Além disso, Silva e Bezerra (2018) expressam que pessoas de cidades circunvizinhas deslocam-se diariamente para São Miguel/RN em busca de comércio e serviços, o que ratifica sua relevância na Região.

Nesta perspectiva, este trabalho tem a finalidade de analisar a expansão urbana do município São Miguel/RN mediante as dinâmicas territoriais a ele associadas.

Além da introdução, o texto está dividido nas seções: Expansão urbana e características das cidades brasileiras, que discorre acerca da ampliação da urbanização do Brasil e do seu reflexo na configuração das cidades; metodologia, que apresenta a área de estudo e descreve os procedimentos metodológicos executados para a concretização deste trabalho; Expansão urbana recente de São Miguel/RN: análise no período de 2000 a 2017, que discute os fatores associados a este aspecto, com foco na mudança das relações de trabalho, na legislação municipal, na produção do espaço a partir dos proprietários da terra e da percepção da população residente, no recorte temporal de 2000 a 2017; considerações finais; agradecimentos. 


\section{EXPANSÃO URBANA E CARACTERÍSTICAS DAS CIDADES BRASILEIRAS}

Nos anos 1940 a população urbana brasileira correspondia a $31,24 \%$ enquanto a rural detinha mais que o dobro deste quantitativo. A partir daí, ocorreu um crescimento gradativo e mais expressivo da taxa de urbanização, marcado principalmente pelo fenômeno da industrialização, que reduziu as possibilidades de produção dos agricultores de pequeno porte e, favoreceu o êxodo rural. Modificou-se consideravelmente o quadro da população urbana e rural do Brasil e a dinâmica ocupacional dos municípios, especialmente no diz respeito à ampliação do perímetro urbano através da ocupação de áreas mais periféricas pelos habitantes recém-chegados na busca de melhores condições de vida.

O processo de industrialização é o que move as transformações da sociedade porque ele é o indutor que caracteriza a sociedade moderna e induz urbanização e a realidade social, estando inclusos os problemas de crescimento e planificação, ou seja, a problemática urbana (LEFEVBRE, 2001).

A partir das décadas de 1940 e 1950, os eixos econômicos fortificam-se no Brasil, impondo dinâmicas urbanas em todo o seu território, quando a industrialização passou a prevalecer em um sentido amplo, incorporando a formação do mercado nacional, esforços para integração dos espaços e a ampliação do consumo, instaurando, assim, a urbanização (SANTOS, 2008; FURTADO, 2002).

Analisando-se os Censos Demográficos do IBGE entre 1940 e 2010, verifica-se que a população predominantemente rural em 1940, modificou-se completamente, variando de 61,78\% em 1940 para $15,64 \%$ em 2010, o que ratifica o inchaço sofrido pelo meio urbano e o esvaziamento rural em um curto intervalo de tempo. Essa alteração radical no cenário brasileiro não foi acompanhada pelo planejamento urbano de órgãos competentes, o que contribuiu para a evolução da segregação socioespacial.

Neste cenário, compreende-se que a cidade é um patrimônio construído histórica e socialmente, porém seu domínio é desigual, uma vez que, enquanto uns têm sua renda assegurada pela especulação imobiliária, outros não têm nem mesmo onde morar e, sendo submetidos à ocupação de áreas de domínio municipal ou de terceiros, até mesmo em localidades de risco e preservação permanente (MARICATO, 2013).

Destaca-se que a ocupação de áreas periféricas é de interesse dos donos da terra, uma vez que sua utilização para fins distintos da agricultura favorece a alteração de áreas antes rurais em urbanas, incorrendo na valorização fundiária, que é mais expressiva na terra urbana do que na rural, e retornando os rendimentos obtidos com a força de trabalho do proletariado em lucro para os próprios detentores do capital. Além disso, contribui-se para o distanciamento entre o espaço dos grupos sociais bem-sucedidos e o espaço daqueles que buscam a subsistência. As derivações deste processo assumem proporções e perfis que se complexificam:

Todas as grandes mazelas urbanas vividas pela maioria da sociedade estão ligadas à produção do espaço urbano sob a forma hegemônica da mercadoria: segregação, dispersão, periferização, carência de serviços, epidemias decorrentes da ausência de drenagem ou terrenos abandonados, violência, longas viagens diárias, ausência de áreas verdes, ocupação de áreas com risco de desmoronamento, impermeabilização exagerada do solo, enchentes, poluição de recursos hídricos, ocupação de áreas ambientalmente frágeis, desmatamento, entre outras (MARICATO; COLOSSO; COMARÚ, 2018, p. 206).

Evidencia-se que o espaço urbano é formado pelos donos dos meios de produção, proprietários fundiários, promotores imobiliários, o Estado, e os grupos sociais excluídos (CORRÊA, 1989). Sobressaem-se os interesses dos agentes dominantes que têm o propósito de reproduzir os meios de produção e acumular capital, perpetuando a ampliação das heterogeneidades urbanas.

Nesta perspectiva, o capitalismo se reproduz através do espaço geográfico, pois sem a expansão, reorganização e desenvolvimento geográfico desigual, ele inexistiria como sistema econômico político; a geografia histórica da acumulação do capital tem sua expressão no ajuste espacial da divisão desigual dos territórios (HARVEY, 2005). A cidade é uma mercadoria especial e o preço das edificações varia com a localização; o valor de acordo com a localização é o negócio da cidade e configura a renda imobiliária; e só mora em um bom local e se tem direito à cidade quem pode pagar (MARICATO, 2015). 
Portanto, nas cidades, além da reprodução da força de trabalho, existe um grande negócio, com disputa entre os que querem melhores condições de vida e aqueles que visam extrair ganhos com sua produção e exploração, gerando lucros, juros e rendas (MARICATO, 2013).

\section{Cidades pequenas no Brasil}

O conceito de cidades pequenas é discutido por alguns autores e entidades por meio de diversas perspectivas: pelo quantitativo populacional, pelo papel regional sobre a rede urbana, pela dinâmica econômica. "Existe uma grande dificuldade na conceituação das pequenas cidades no Brasil, devido, sobretudo, à quantidade e à diversidade e à proximidade delas com o meio rural, gerando uma complexa confluência entre o urbano e o rural" (FERNANDES, 2018, p. 14).

Exemplos da classificação pelo critério populacional são: a do Ministério de Desenvolvimento Social e Combate à Fome (2004), que expõe que as cidades podem ser classificadas através do quantitativo populacional pelos portes Pequeno I (até 20.000 habitantes), Pequeno II (de 20.001 a 50.000 habitantes), Médio (de 50.001 a 100.000 habitantes), Grande (de 100.001 a 900.00 habitantes) e Metrópole (a partir de 900.001 habitantes); e a do IBGE (2016): Pequena (até 100.000 habitantes), Média (de 100.001 a 500.000 habitantes) e Grande (Superior a 500.000 habitantes).

Uma cidade classificada como média em 1950 ou 1960, não pode ser considerada uma cidade média em décadas posteriores, pois em um determinado momento uma cidade com mais de 20.000 habitantes poderia ser denominada como média, mas em outro, uma cidade média necessita ter em torno de 100.000 habitantes (SANTOS, 2008).

Dados do censo demográfico de 2010 do Instituto Brasileiro de Geografia e Estatística (IBGE) mostram que no Brasil, dos 5.565 municípios, 5.282 possuem uma população inferior a 100.000 habitantes, o equivalente a $94,91 \%$ do total.

Além disso, segundo o IBGE (2011), 4.957 municípios têm população até 50.000 habitantes, resultando em uma população total de 64.004 .918 habitantes, ou seja, $89,07 \%$ do total de municípios estão nesta categoria, abrigando $33,55 \%$ da população brasileira. Em se tratando de Nordeste, 1.623 municípios apresentam essa característica (90,47\% do total). No Rio Grande do Norte, dos 167 municípios que o compõem, 159 possuem essa configuração. Este panorama mostra a importância das pesquisas voltadas para as cidades pequenas, tendo em vista a sua maior representatividade numérica.

Maia (2010) expressa que mesmo que a demografia seja um dado importante, ela por si só não caracteriza as cidades, uma vez que não traduz a dinâmica das cidades, exemplificando que uma cidade de 100.000 habitantes no interior da Bahia não possui a mesma dinâmica de uma cidade com a mesma quantidade de pessoas no Estado de São Paulo. Fernandes (2018) discorre que o entendimento de cidades pequenas engloba o aspecto quantitativo, a partir de número máximo e mínimo de habitantes, e qualitativo, associado às inter-relações na rede urbana e formação socioespacial das regiões.

Independentemente da definição, as cidades pequenas têm uma elevada contribuição para o Brasil, carecendo de estudos que busquem explicar seu cenário urbano, o que ocorre de forma abrangente com cidades grandes e metropolitanas. Sposito e Jurado da Silva (2013) relatam que embora seja uma temática rica a ser investigada, as cidades pequenas não têm sido prioridade para as pesquisas voltadas para a geografia urbana e geografia econômica no Brasil e no Mundo. Manfio (2019) aborda que análises urbanas durante muito tempo estavam concentradas nas metrópoles e em grandes centros, mesmo que os centros menores tenham características, modos de vida e estruturas econômicas que exercem influência na rede urbana em que estão inseridos; o que impõe dificuldades em pesquisas atuais devido à limitação de conceituação e bibliografia.

Neves e Faria (2020) realizaram o levantamento do quantitativo de teses e dissertações que tratam do espaço urbano das cidades pequenas no período de 2009 a 2018. Os autores identificaram 62 trabalhos, dos quais $84 \%$ foram produzidos em instituições de ensino superior públicas, com crescimento mais constante a partir de 2015 e pequeno recuo em 2018. Eles também discorrem que 46 dos 62 trabalhos possuem orientadores específicos, o que demonstra uma ausência de sistematização de pesquisas nesta área, ao contrário do que ocorre com as cidades médias, grandes e regiões metropolitanas.

Fernandes e Correia (2018) destacam que as cidades pequenas possuem os mesmos problemas que as cidades grandes, uma vez que os seus processos de urbanização foram semelhantes, ou seja, o

Caminhos de Geografia Uberlândia-MG $\quad$ v. 22, n. $80 \quad$ abr./2021 $\quad$ p. 182-200 Página 185


capitalista. Esse elemento reafirma a necessidade de trabalhos voltados para tal padrão de cidade, como é o caso de São Miguel/RN.

\section{METODOLOGIA}

\section{Área de Estudo}

O objeto de análise desta pesquisa é a área urbana do município de São Miguel/RN (Figura 1). De acordo com o censo de 2010 do IBGE, este município possui 22.157 habitantes, 14.500 habitantes na zona urbana e 7.657 na zona rural, com percentuais de $65,44 \%$ e $34,56 \%$, respectivamente.

Figura 1 - Localização de São Miguel/RN.

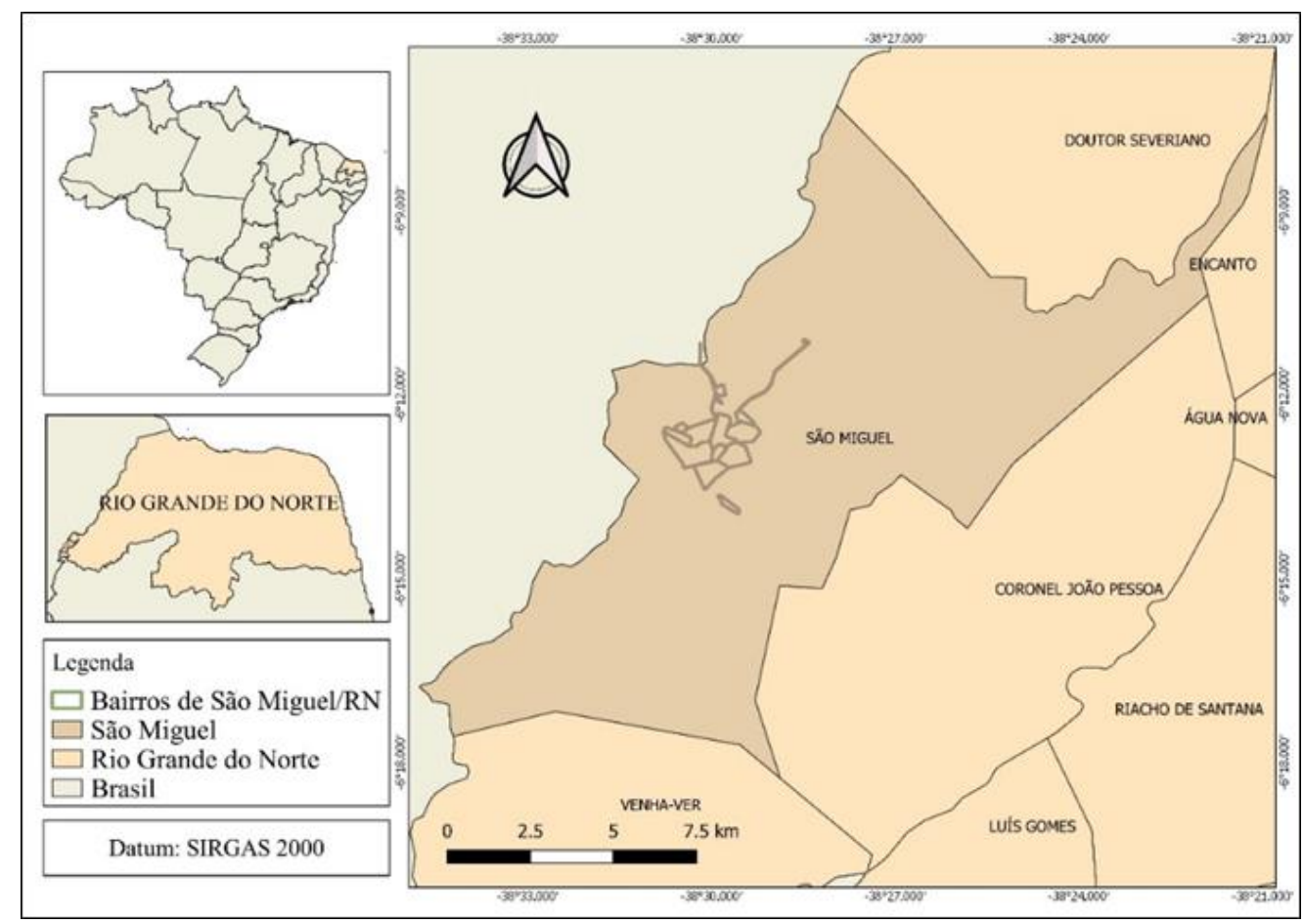

Fonte - Malhas Digitais do IBGE (2019); Prefeitura Municipal de São Miguel/RN (2017); e Google Earth Pro (2018). Elaboração Gráfica dos Autores (2020).

Segundo a Prefeitura Municipal de São Miguel/RN (2017), em 1936, por meio da Lei no 88 de 12 dezembro, São Miguel tornou-se cidade. Posteriormente, foram desmembrados de seu território os distritos Mundo Novo (em 1962), Baixio de Nazaré (em 1963) e Padre Cosme (em 1992), atualmente denominados Doutor Severiano, Coronel João Pessoa e Venha-Ver, respectivamente.

O município de São Miguel/RN situa-se na mesorregião Oeste Potiguar e na microrregião Serra de São Miguel; a sede do município tem uma altitude média de $679 \mathrm{~m}$ e coordenadas $06^{\circ} 12^{\prime} 43,2^{\prime \prime}$ de latitude sul e $38^{\circ} 29^{\prime} 49,2^{\prime \prime}$ de longitude oeste, distando da capital do Rio Grande do Norte cerca de 460 km; está totalmente inserido nos domínios da bacia hidrográfica Apodi-Mossoró, sendo banhado apenas por cursos d'água secundários e intermitentes. O clima é tropical chuvoso com verão seco e estação chuvosa adiantando-se para o outono; a vegetação é composta pela caatinga hiperxerófila, vegetação de caráter mais seco com abundância de cactáceas e plantas de porte mais baixo e espalhadas, e pela Floresta Caducifólia, que apresenta espécies de folhas pequenas e caducas que caem no período seco (Companhia de Pesquisa de Recursos Minerais - CPRM, 2005).

O IBGE (2011) aponta que 52,1\% da população de São Miguel/RN tem renda mensal igual ou superior a meio salário mínimo e a mortalidade infantil é de 15,58 óbitos por mil nascidos vivos. O Atlas Brasil (2010) expressa que Índice de Desenvolvimento Humano Municipal (IDHM), que envolve variáveis de renda educação e longevidade, é de 0,606 , classificado como médio.

$\begin{array}{lllll}\text { Caminhos de Geografia } \quad \text { Uberlândia-MG } & \text { v. 22, n. } 80 & \text { abr./2021 } & \text { p. 182-200 } & \text { Página } 186\end{array}$




\section{Procedimentos Metodológicos}

Para a efetivação deste trabalho, fizeram-se necessárias as etapas:

a) Coleta de informações do Produto Interno Bruto (PIB) de serviços e concessão de benefícios do município em portais online para a discussão relativa à modificação da representatividade da população urbana;

b) Solicitação à Secretaria Municipal de Administração, Finanças, Planejamento e Orçamento São Miguel/RN - Setor de Tributação - da lista de loteamentos registrados no período de 2000 a 2017; consulta à prefeitura, à Secretaria Municipal de Desenvolvimento Urbano e ao portal municipal de São Miguel/RN para que fosse realizado o levantamento das leis de inserção de áreas no perímetro urbano e de denominação de bairros entre 2000 e 2017 e que se obtivesse o acesso ao Plano Diretor Participativo, que trata sobre o perímetro urbano deste município, com o intuito de debater a influência do Plano Diretor Participativo e dos loteamentos na produção do espaço urbano recente de São Miguel/RN. A demarcação desses loteamentos em mapa foi realizada com base em escrituras existentes no processo de solicitação de sua implantação na Secretaria de Desenvolvimento Urbano e coletadas em cartório de registro de imóveis e, pelo conhecimento da Tabeliã de Registro de Imóveis e do chefe do Departamento de Fiscalização de Obras de São Miguel/RN;

c) Pesquisa no Tribunal de Contas da União do quantitativo monetário resultante do Imposto Territorial Predial Urbano (IPTU) obtido de 2003 a 2011 pelo município de São Miguel/RN, de modo a verificar a evolução deste imposto no tempo. Destaca-se a intenção de verificação do período a partir de 2000 , entretanto o Portal da Transparência não continha dados de 2000 a 2002. Ressalta-se ainda que foi executada a solicitação à Secretaria Municipal de Administração, Finanças, Planejamento e Orçamento São Miguel/RN - Setor de Tributação -, no entanto, devido período prescricional de dívida de 5 anos adotado pelo município, as informações disponibilizadas foram do intervalo de tempo de 2012 a 2017.

d) Realização de entrevistas semiestruturadas com prefeito municipal; historiador e colunista; chefe do departamento de fiscalização de obras; e com moradores de São Miguel/RN. Essas entrevistas compuseram uma pesquisa maior, a Dissertação de Mestrado intitulada "Dinâmica Urbana e Regularização Fundiária: um estudo acerca da cidade de São Miguel/RN".

- As indagações ao Prefeito Municipal foram: A que o Senhor atribui a elevada expansão urbana de São Miguel no período de 2000 a 2017? Quais critérios são observados para inserir uma área no perímetro urbano da cidade?

- O historiador e colunista; o chefe do departamento de fiscalização de obras; e os moradores de São Miguel/RN foram interrogados a partir do roteiro: Quantos anos você tem? Há quando tempo reside na cidade de São Miguel/RN? Conte sobre o antes o depois da cidade de São Miguel/RN; Quais as mudanças na infraestrutura ocorridas ao longo do tempo? e outras que foram sendo realizadas no decorrer do diálogo voltadas para o objeto de estudo desta pesquisa;

- Os moradores entrevistados tinham idade igual ou superior a 60 anos e residentes em São Miguel/RN há pelo menos 30 (trinta) anos, intervalo de tempo que permite uma percepção de mudanças que possam ter ocorrido no cenário urbano, estavam aptos a responder às perguntas e que concordaram em colaborar de forma voluntária para esta pesquisa. O tamanho da amostra composta por moradores foi definido com base no critério de saturação, que é conceituado por Fontanella, Ricas e Turato (2008) como uma ferramenta utilizada em pesquisas qualitativas para estabelecer o tamanho da amostra de um estudo, através da qual é suspensa a inclusão de novos participantes quando os resultados são considerados repetitivos pelo pesquisador, o que implica que sua continuidade não contribui significativamente para a análise em questão. As entrevistas ocorreram em todos os bairros da cidade na dissertação supracitada e este trabalho foram utilizadas as pertinentes.

- Solicitou-se aos participantes entrevistados a assinatura do Termo de Consentimento Livre e Esclarecido e do Termo de Autorização para Uso de Áudio. Diante desses instrumentos, as entrevistas foram gravadas. Com a finalidade de garantir o anonimato dos moradores entrevistados, estes foram nomeados como Entrevistado seguido do nome do bairro que ele habita. Os demais entrevistados não tiveram seu nome exposto e foram citados de acordo com a função que exercem nas instituições que atuam. Esses procedimentos metodológicos foram condicionados à aprovação do Comitê de Ética Profissional da Universidade do Estado do Rio Grande do Norte, com parecer sob o número 2.610.860, datado de 20 de abril de 2018. 
e) Representação da mancha urbana de São Miguel/RN com o software gratuito Qgis versão 2.14.21, a partir de malhas disponibilizadas em bases online do IBGE dos anos de 2000, 2007 e 2010; montagem da mancha urbana de 2017 por meio do Mapa de Zoneamento de São Miguel/RN deste ano, disponibilizado pela Prefeitura Municipal; captura de imagens de satélites que mostram a ampliação da ocupação de terras urbanas ou de expansão entre os anos de 2009 e 2016.

\section{EXPANSÃO URBANA RECENTE DE SÃO MIGUEL/RN: ANÁLISE NO PERÍODO DE 2000 A 2017,}

Seguindo os mesmos direcionamentos a nível nacional, o município de São Miguel teve sua população urbana em maior escala que a rural a partir do século XX, em que sua modificação se deu gradativamente ao longo dos anos, conforme mostra a Figura 2.

Figura 2 - Evolução da População Urbana e Rural de São Miguel/RN.

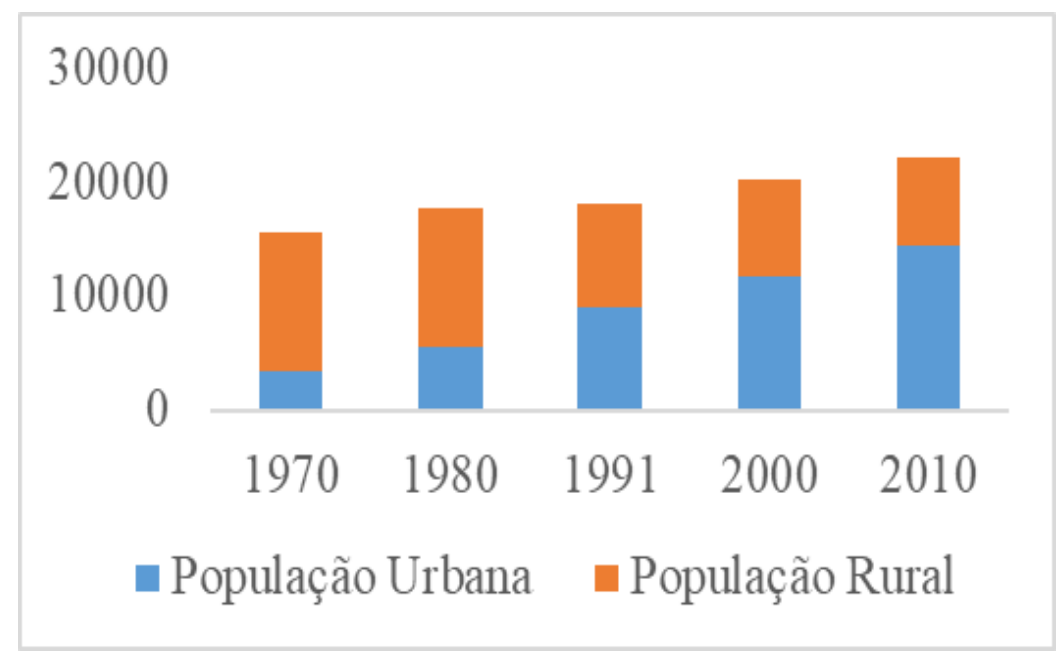

Fonte - IBGE, Censos Demográficos de 1970, 1980, 2000 e 2010; Atlas Brasil - Censo Demográfico do IBGE de 1991. Elaboração Gráfica dos Autores (2018).

Não foi apenas a população que cresceu ao longo do tempo, o território urbano de São Miguel/RN se expandiu significativamente no período de 2000 a 2017, o que pode ser verificado pela espacialização da mancha urbana deste município neste intervalo temporal mostrada na Figura 5.

Fahmi et al. (2014) mencionam que dentre os fatores que podem estimular o desenvolvimento urbano em cidades menores estão a reestruturação econômica, a mudança demográfica, o planejamento e os processos políticos. Silva e Bezerra (2018) apontam que a expansão urbana de São Miguel/RN, a partir de 2000, está associada à atração populacional da zona rural desta cidade para a zona urbana e de cidades circunvizinhas, motivada pela ampliação do setor terciário deste município. Frisam ainda que diariamente há o deslocamento de pessoas de cidades vizinhas e de outras localidades do Ceará, estado vizinho, em busca de produtos no comércio e de serviços públicos, o que contribui para esta expansão.

A atração populacional para a Zona Urbana no período de 2000 a 2017 também pode ser afirmada pela vinda de pessoas de outras localidades, além da zona rural e das cidades circunvizinhas, como exposto por Silva e Bezerra (2018). O IBGE (2011) aponta que 1.051 habitantes do município de São Miguel/RN não residiam nesta localidade até 31 de dezembro do ano de 2005, isto é, em 2010 havia 1.051 pessoas que migraram para este município a partir de 2006, sendo que destas, 986 se encontravam com situação domiciliar na zona urbana e 65 na zona rural. O quadro migratório corresponde a $4,74 \%$ da população total de 2010 (22.157 habitantes) e o contingente urbano compreende a $6,8 \%$ da população com situação domiciliar urbana (14.500 habitantes) de 2010 . Os Estados mais expressivos de origem desta migração foram Ceará e São Paulo, com 395 e 232 habitantes, respectivamente. Embora a migração não interfira em grande escala no quantitativo populacional, ela pode alterar significativamente a dinâmica urbana de São Miguel/RN, seja no 
comércio, no crescimento do número de edificações, na demanda por serviços, na ampliação da irregularidade fundiária, dentre outros, o que contribui para a expansão urbana de São Miguel/RN.

Entrevistas realizadas com moradores que habitam na zona urbana de São Miguel/RN mostram que muitos deles saíram da zona rural para a zona urbana pela facilidade de acesso aos serviços, seja estudo para os filhos e oportunidade de trabalho (quando ainda jovens), seja pela possibilidade de atendimento de saúde ou proximidade com familiares (os mais velhos), ou porque se aposentaram e esta renda permite a saída do campo. O historiador e colunista de São Miguel/RN cita ainda a realização de concursos, que concedeu empregos a muitas pessoas e, por consequência, a sua vinda para a cidade.

A concentração das populações nos centros urbanos está associada a uma busca constante pelos serviços existentes nas zonas urbanas. Para manter as populações em seus locais de origem, nas zonas rurais, que são muito mais propícias a uma vida confortável do que as cidades adensadas, é necessário levar equipamentos que permitam as relações de vida e convivência que forneçam padrão de acesso aos serviços iguais ou semelhantes aos da cidade (PREFEITO MUNICIPAL DE SÃO MIGUEL/RN, 2018).

Por meio das relações citadas que impulsionaram a vivência no território urbano, compreende-se que o processo de urbanização também está associado às mudanças de trabalho por meio do salário e da acessibilidade aos equipamentos que o espaço urbano disponibiliza, tais como escolas e centros de saúde. Outro elemento que pode cooperar para o crescimento das cidades é a "economia sem produção", relacionada com as aposentadorias e recursos de políticas compensatórias do Governo Federal injetados nas cidades, pois favorece a vinda da população rural para a urbana e aquece o dinamismo do comércio local (ARAÚJO e LIMA, 2009). Este aspecto é citado por alguns moradores durante as entrevistas realizadas para esta pesquisa no momento que se dialoga sobre os possíveis motivos que ocasionaram a expansão urbana acentuada de São Miguel/RN, por exemplo: "Os que vêm do sítio faz crescer melhor do que os que já estão aqui quase né!?. [...] O aposento é a felicidade do povo. Se não fosse o aposento já tinha morrido o povo aqui quase todo de fome" (MORADOR DO BAIRRO MARIA MANOELA, 2018). O historiador e colunista de São Miguel/RN também discorreu que a aposentadoria foi um dos fatores impulsionadores da vinda da população da zona rural para a zona urbana.

A ampliação da concessão de benefícios em São Miguel/RN é confirmada por meio de dados da Secretaria da Previdência (2018), que mostram que em 2000 foram emitidos 4.721 benefícios, enquanto que em 2017 esse valor foi de 8.432, o que favorece a "economia sem produção", que de acordo com Medeiros (2005) dinamiza as relações comerciais e atua no aquecimento do comércio local, que têm suas atividades ampliadas no período de recebimento dos recursos provenientes de aposentadorias e de outros programas de transferência de renda implantados pelo governo.

A evolução do setor terciário, expressa como motivador da expansão do espaço urbano por Silva e Bezerra (2018) é ratificada observando-se o PIB do município de São Miguel/RN do período de 2002 a 2015, descrito pelo IBGE (2017) e com valores deflacionados por meio do Índice Nacional de Preços ao Consumidor Amplo (IPC-A): o valor para o setor de Serviços foi de R $\$ 76.007,00$ em 2002 e de $R \$ 162.588,00$ em 2015 , isto é, houve uma evolução de $113,91 \%$, o que pode ser considerado como um dos fatores do crescimento urbano acelerado de São Miguel/RN no intervalo de análise deste estudo (2000 a 2017). Destaca-se que um dos principais contribuintes para a ascensão do setor terciário foi o setor público, que teve representatividade no PIB de serviços entre $70 \%$ e $60 \%$ no período de 2002 a 2015.

Dantas e Silva (2011) enfatizam que a maior parte do setor terciário das principais cidades do Alto Oeste Potiguar, que inclui São Miguel/RN, com exceção de Pau dos Ferros/RN, é formado pelo setor público, que reflete diretamente no total de pessoas ocupadas: participação dos serviços públicos no PIB do setor de serviços desses municípios é em média de $50 \%$.

O setor terciário engloba o setor privado e o público, em que este último tem grande influência no nível da renda e dos empregos urbanos. Como aspecto impactante do setor terciário, cita-se a ação das políticas públicas, especialmente as voltadas para a urbanização, uma vez que elas influenciam por processos econômicos, sociais e políticos as interações do setor terciário com os demais setores da economia local (CLEMENTINO, 1995).

Medeiros (2005) elenca que os serviços sociais contribuíram diretamente para o crescimento do núcleo central das pequenas cidades do Seridó, que teve uma maior dinamização por meio da

Caminhos de Geografia Uberlândia-MG $\quad$ v. 22, n. $80 \quad$ abr./2021 $\quad$ p. 182-200 Página 189


construção e ampliação de escolas, hospitais públicos e postos de saúde. A autora relata que as características demográficas e os equipamentos de serviços são elementos importantes para a compreensão da dinâmica das cidades a partir do momento que orientam a produção do espaço urbano. Em São Miguel/RN também houve uma implementação de equipamentos urbanos que além de favorecerem a expansão urbana, colaboraram para o incremento do setor terciário, como é o caso de construções, ampliações e reformas de creches, postos de saúde, hospital, praças, lagoa e de quadras poliesportivas a partir do ano de 2005 , citados por muitos entrevistados.

Neste sentido, verifica-se que o poder público é um dos agentes promotores da produção do espaço urbano à medida que incorporara instituições públicas e amplia a quantidade de empregados no funcionalismo público, elementos que incrementam as atividades comerciais.

Como fator cooperador à expansão significativa de São Miguel/RN, menciona-se também a inclusão de áreas rurais no perímetro urbano da cidade por meio de instrumentos legais municipais como Plano Diretor Participativo e Leis de Inclusão de áreas no Perímetro Urbano.

O Plano Diretor Participativo de São Miguel/RN foi instituído Lei oㅜ 656/2008 e é apresentado como o instrumento básico de ordenamento físico-territorial do município e de orientação dos agentes públicos e privados que atuam na produção e gestão do espaço urbano e rural. O gestor municipal de São Miguel/RN (2018) expressou que os motivos para incluir áreas no perímetro urbano são as relações territoriais que essas áreas exercem, a disponibilidade dos serviços existentes nestas localidades.

A malha urbana de 2007 apontada na Figura 5 engloba áreas ocupadas por construções e vias e pelas áreas de expansão, coincidindo com o polígono do Plano Diretor Participativo de São Miguel/RN que é apresentado na Figura 3.

Figura 3 - Sede urbana de São Miguel/RN 2007.

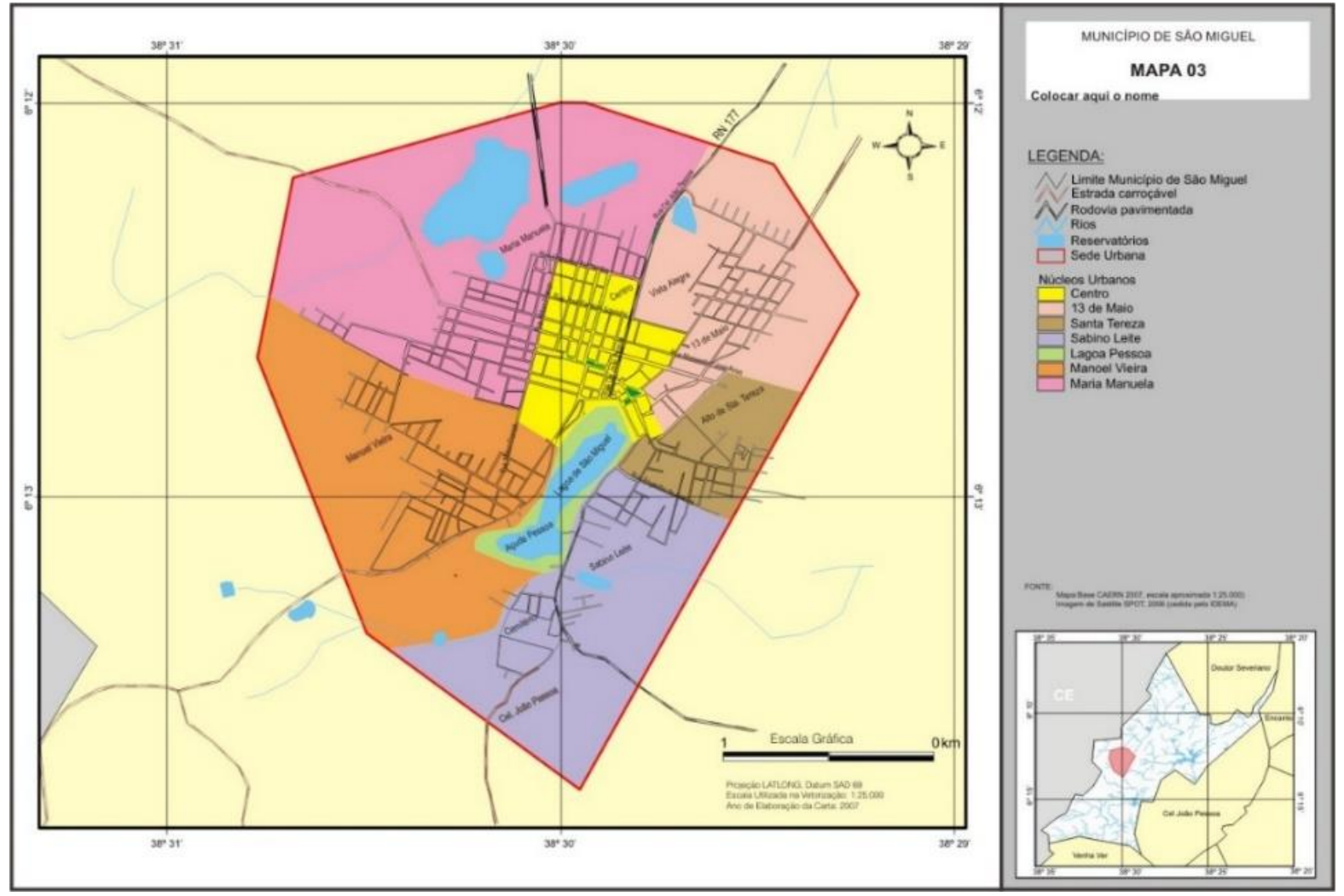

Fonte - Plano Diretor Participativo de São Miguel/RN (2008).

O capital imobiliário especulativo pode ocorrer pelo poder público no processo de formatação e aprovação do Plano Diretor da cidade, onde se definem os direcionamentos de crescimento do

Caminhos de Geografia Uberlândia-MG $\quad$ v. 22, n. $80 \quad$ abr./2021 $\quad$ p. 182-200 Página 190


espaço urbano, a instalação de equipamentos públicos e conjuntos habitacionais; e pelo privado, quando o agente imobiliário transforma a gleba em um ativo imobiliário com o intuito de valorizá-lo ficticiamente (MIRANDA, 2002).

Assim, a expansão urbana é uma estratégia de uso da terra e se origina de práticas de planejamento local e de transformações em seu uso (PAGLIARIN, 2018). Ou seja, a atuação dos agentes produtores do espaço urbano Estado e Latifundiários, através da legislação urbana e dos interesses capitalistas, respectivamente, resulta no favorecimento do crescimento da malha das cidades.

Conforme expresso na Figura 3, a cidade era dividida em apenas seis bairros: Centro, 13 de Maio, Santa Tereza, Sabino Leite, Manoel Vieira e Maria Manoela. No decorrer dos anos as áreas de expansão foram sendo parceladas, desencadeando o crescimento da zona efetivamente urbana e em um quantitativo maior de bairros, incidindo na configuração exposta no Mapa de Zoneamento de São Miguel/RN, do ano de 2017, contido na Figura 4.

Figura 4 - Mapa de Zoneamento de São Miguel/RN 2017.

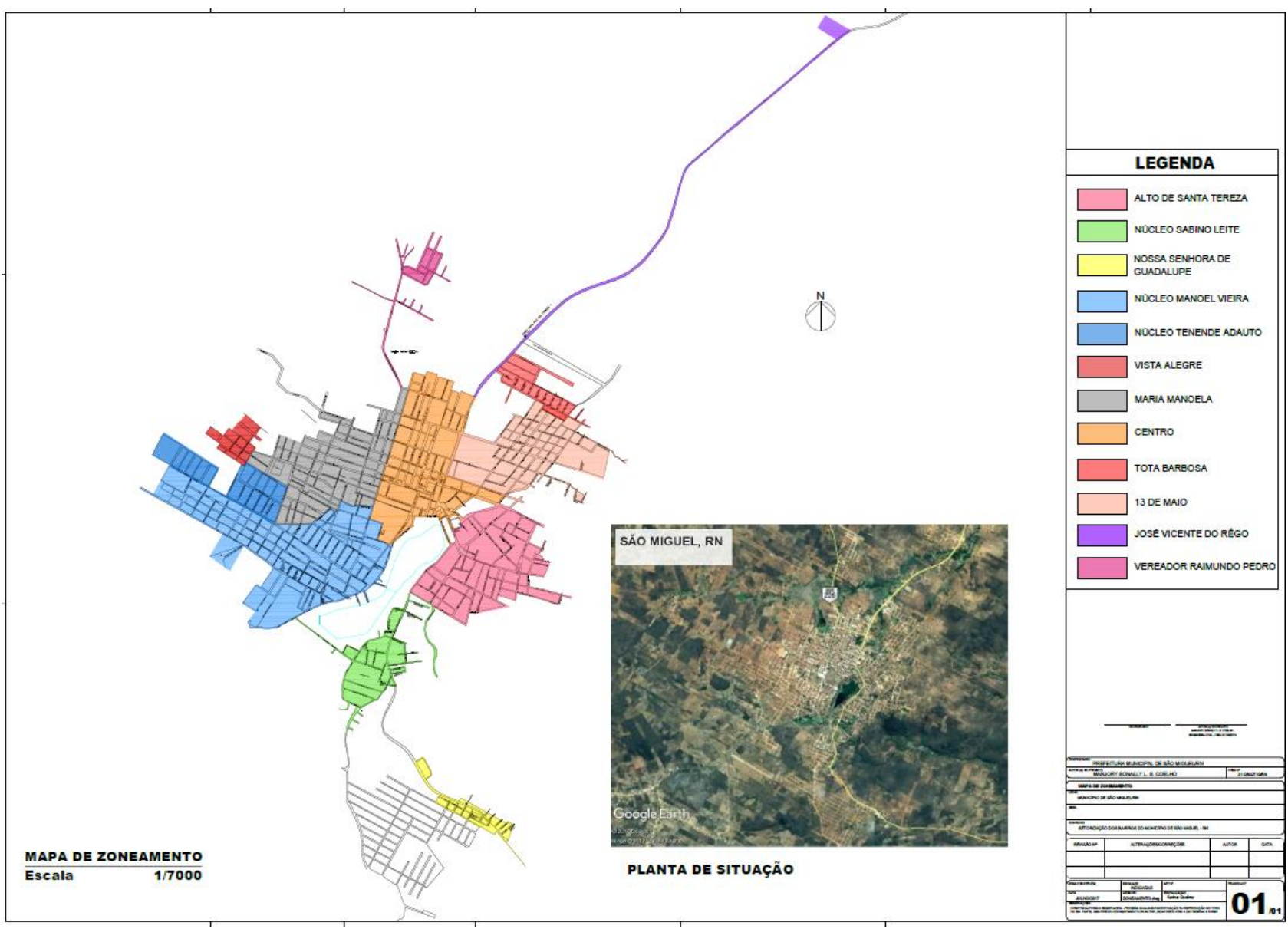

Fonte - Prefeitura Municipal de São Miguel/RN (2017).

Por meio da Figura 4, é possível identificar o elevado número de vias se comparado ao apresentado na Figura 3, o que comprova a ampliação da malha urbana, seja através de elementos que parcelam o espaço sejam com o parcelamento e ocupação do solo. Esta ampliação se deu além das faixas de expansão urbana apresentadas no Plano Diretor Participativo, o que pode ser percebido pela Figura 5, que mescla, em seu último cenário, o mapa de zoneamento do ano de 2017 elaborado pela Prefeitura Municipal de São Miguel/RN com a malha urbana de 2010 elaborada pelo IBGE.

$\begin{array}{llll}\text { Caminhos de Geografia } \quad \text { Uberlândia-MG } & \text { v. 22, n. } 80 \quad \text { abr./2021 } & \text { p. 182-200 Página } 191\end{array}$


Figura 5 - Mancha Urbana de São Miguel/RN nos anos de 2000, 2007, 2010 e 2017.
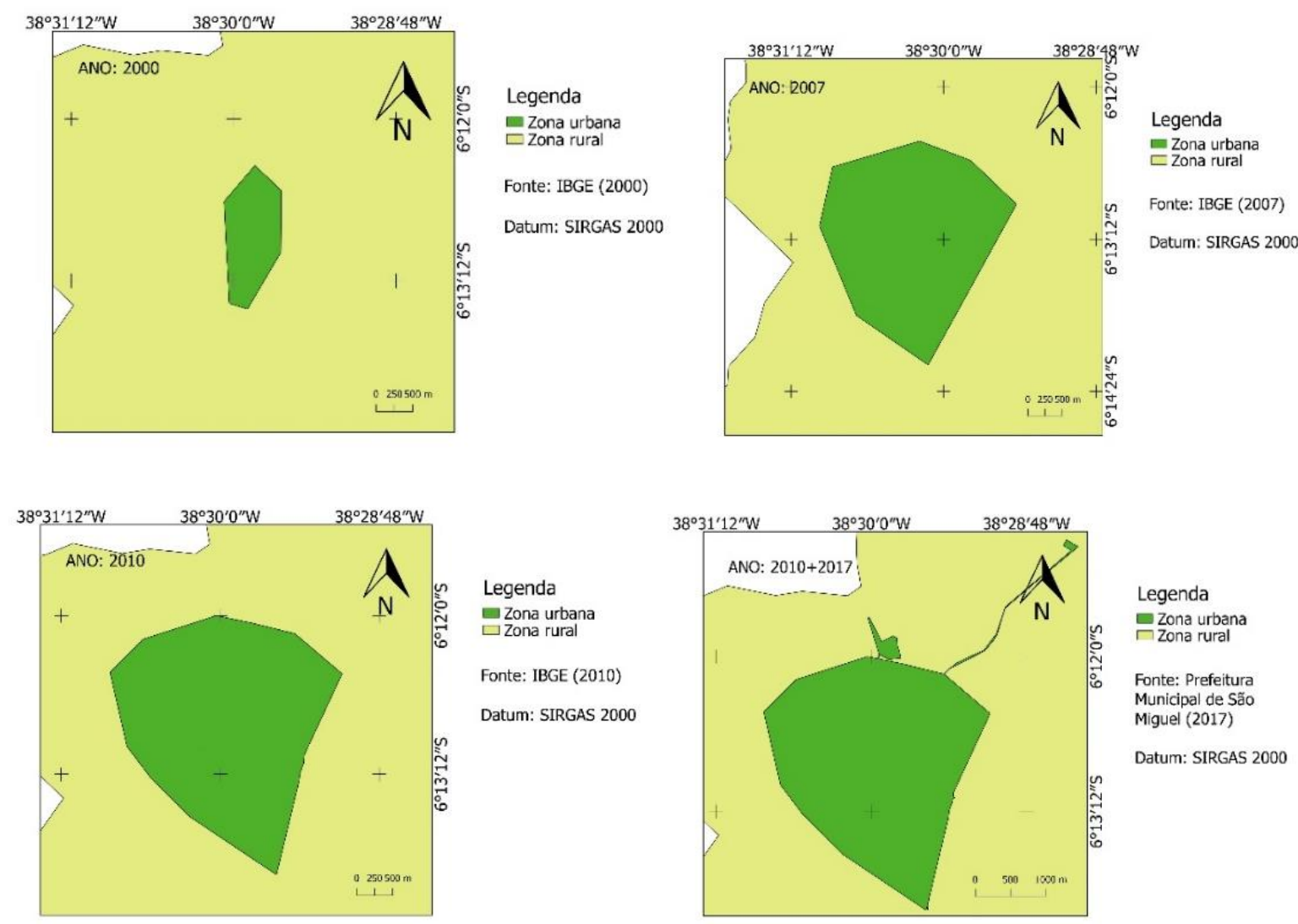

Legenda

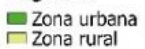

Fonte: Prefeitura Municipal de São Miguel (2017)

Datum: SIRGAS 2000

Fonte - Malhas do IBGE (2000), (2007) e (2010), e Prefeitura Municipal de São Miguel/RN (2017). Elaboração Gráfica dos Autores (2018).

A Figura 5 mostra que a malha urbana de São Miguel/RN delimitada em período anterior à confecção do Plano Diretor Participativo era restrita (2000), cenário que foi modificado com a instauração deste instrumento de ordenamento territorial, que incluiu no perímetro urbano áreas de expansão e, dessa forma, colaborou para a valorização imobiliária. A expansão real da cidade superou a previsão do Plano Diretor Participativo, resultando em malhas urbanas mais extensas como a de 2010 e, mais ainda, a de 2017, que apresenta como integrantes do espaço citadino o bairro Vereador Raimundo Pedro, localizado em área adjacente à de expansão urbana, e o bairro José Vicente do Rêgo, que apresenta-se mais distante da delimitação da zona de expansão.

Ao ser indagado sobre os motivos da expansão urbana elevada de São Miguel no período de 2000 a 2017, o prefeito municipal respondeu que a dinâmica, mais especificamente na questão dos fluxos populacionais, é decorrência de alguns atrativos gerados, de modo que as pessoas procuram ser melhor atendidas. Destacou que São Miguel, apesar de estar localizado no sertão, tem características climáticas e geomorfológicas diferenciadas de outros municípios situados nesta área, sendo tratado sempre como um local de produção de gêneros alimentícios. Assim, o crescimento urbano no período de 2000 a 2017 está relacionado à estas particularidades. "São Miguel é o que é pela formação, pela sua história, pela sua vocação" (PREFEITO MUNICIPAL DE SÃO MIGUEL/RN, 2018).

As Figuras 6 e 7 correspondem a imagens de satélite que englobam os bairros mais consolidados nos anos de 2009 e 2016 e que facilitam a visualização da modificação ocorrida no espaço ao longo dos anos. 
Figura 6 - Cidade de São Miguel/RN no ano de 2009.

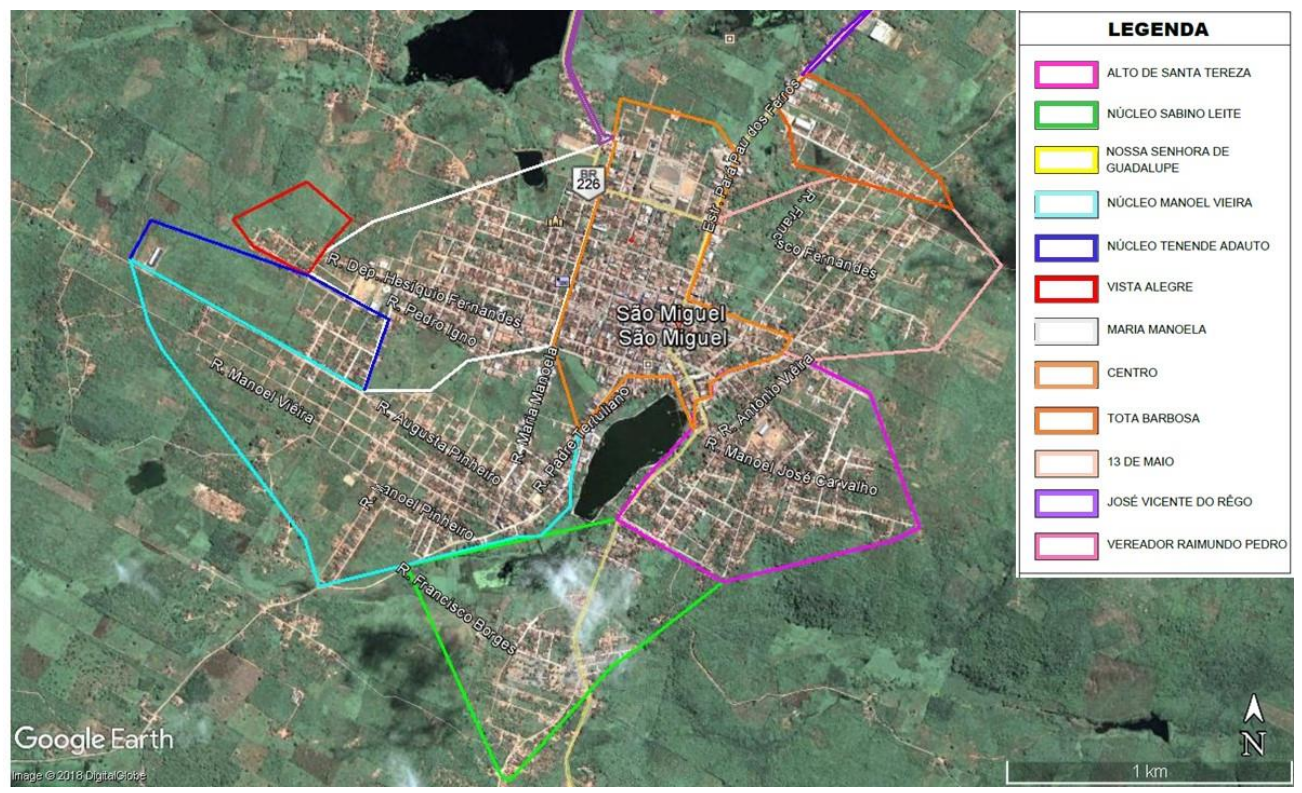

Fonte - Google Earth Pro (2009). Elaboração Gráfica dos Autores (2018).

Figura 7 - Cidade de São Miguel/RN no ano de 2016.

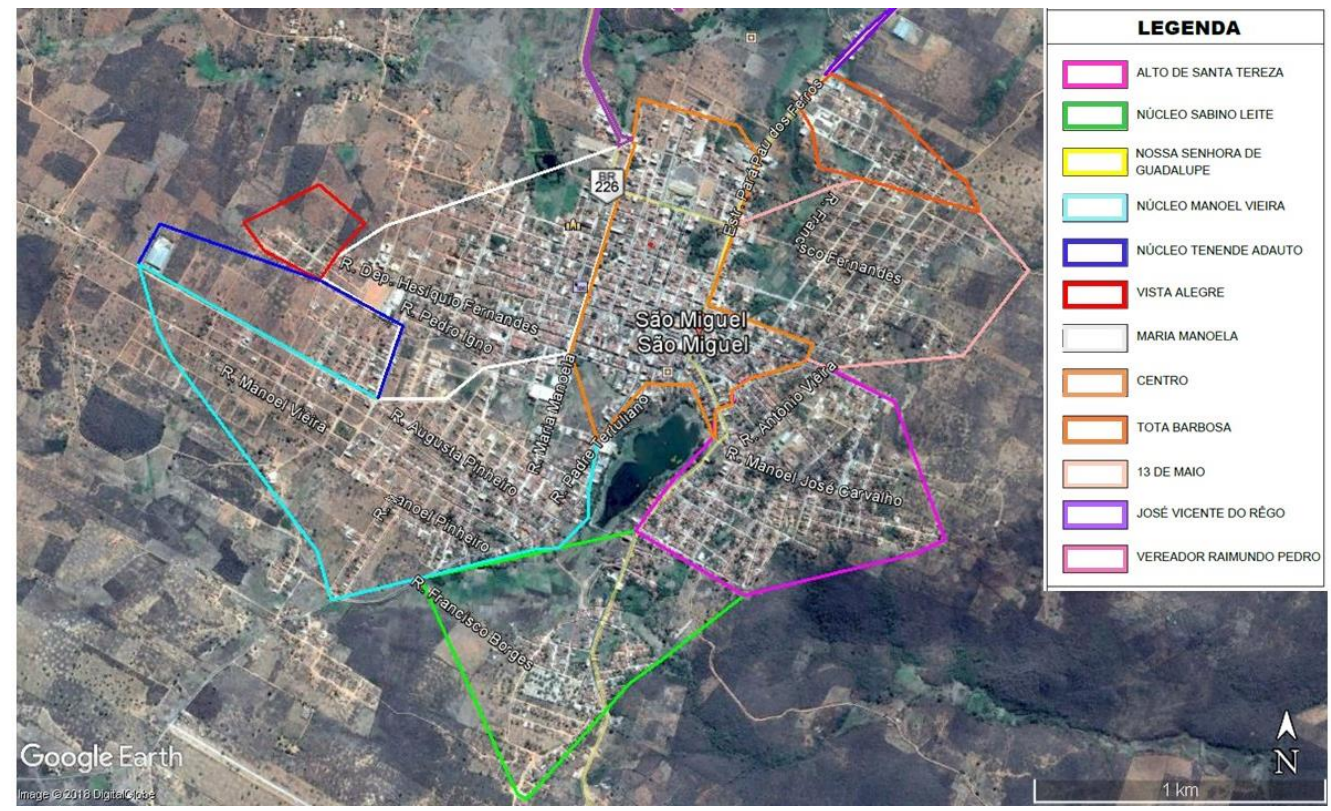

Fonte - Google Earth Pro (2016). Elaboração Gráfica dos Autores (2018).

Imagens de um intervalo temporal mais longo permitiriam a demonstração mais fiel da intensa expansão urbana de São Miguel/RN no período de 2000 a 2017. Entretanto, o Google Earth Pro contemplava somente imagens dos anos de 2003, 2008, 2009 e 2016 quando este estudo foi executado, em que as dos dois primeiros anos correspondem apenas da delimitação de quadras e vias. Comparando-se as Figuras 6 e 7, percebe-se que todos os bairros mostrados tiveram ampliação no número de vias e edificações. Como ente colaborativo dessa urbanização e expansão, listam-se os loteamentos instaurados nesta cidade. O relatório de loteamentos abertos entre 2005 e 2016 disponibilizado pela Secretaria Municipal de Administração, Finanças, Planejamento e Orçamento de São Miguel/RN - Setor de Tributação (2018), mostrou a incidência de 20 loteamentos neste período. Não há registros de loteamentos para o ano de 2017 no setor de Tributação. 
A Figura 8 expõe a localização e extensão aproximada dos loteamentos inseridos na área urbana listados pela Secretaria Municipal de Administração, Finanças, Planejamento e Orçamento de São Miguel/RN - Setor de Tributação (2018), com exceção de três deles. Neste caso, dois não tiveram espacialização identificada devido à ausência de escritura da área anexada ao processo de liberação da implantação na Secretaria de Desenvolvimento Urbano (mesmo que particular), a ocorrência de imprecisão da localização das plantas de parcelamento, que as limitam apenas com ruas projetadas, e do desconhecimento da localização pelo Chefe do Departamento de Fiscalização de Obras do município de São Miguel/RN. O terceiro não foi disposto porque trata-se de um loteamento em área rural. A localização dos loteamentos é aproximada porque grande parte deles não possui escritura pública e os que possuem não têm delimitação georreferenciada, sendo descrito apenas por nome de pessoas proprietárias de terras confinantes ou mesmo por ruas denominadas como projetadas. Dessa forma, a representação espacial foi feita adotando as matrículas existentes, indicação da Tabeliã de Registro de Imóveis para as essas áreas e, as declarações do Chefe do Departamento de Fiscalização de Obras do município de São Miguel/RN.

Figura 8 - Loteamentos de São Miguel/RN entre 2005 e 2016.

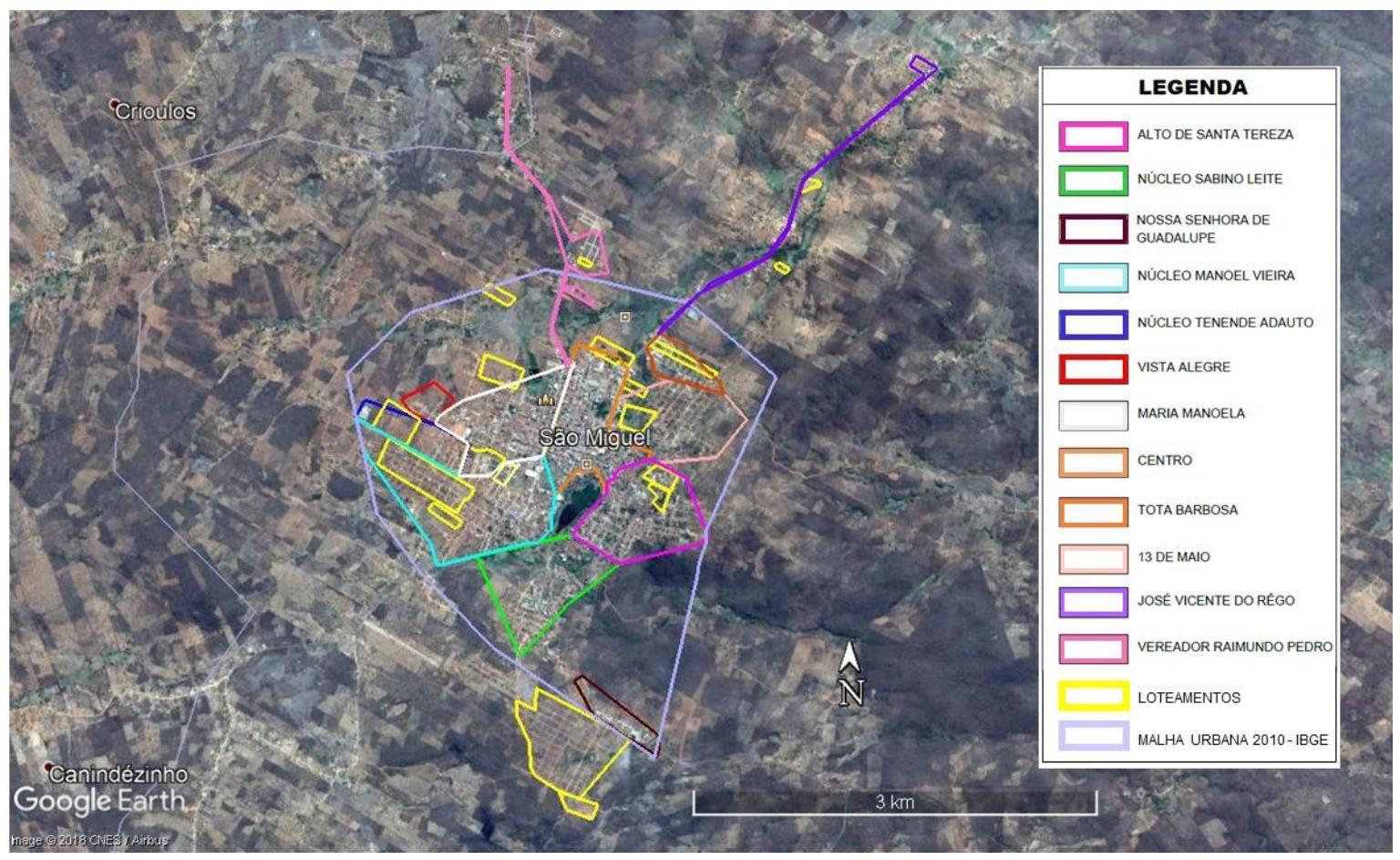

Fonte - Google Earth Pro (2016). Elaboração Gráfica dos Autores (2018).

Por meio da Figura 8 percebe-se a elevada quantidade territorial que foi parcelada no período de 2005 a 2016. O parcelamento do solo ultrapassa os limites da poligonal da sede urbana de São Miguel/RN de 2010, realidade que não tem amparo legal, pois a Lei oㅡ 6.766/1979 expressa no Art. $3^{\circ}$ que somente será admitido o parcelamento do solo para fins urbanos em zonas urbanas, de expansão urbana ou de urbanização específica, assim definidas pelo Plano Diretor ou aprovadas por Lei Municipal. Esta situação reflete a expectativa da continuidade da expansão urbana gerada pelo parcelamento do solo. O relato do Chefe do Departamento de Fiscalização de Obras expressa que além dos loteamentos apresentados pela Secretaria Municipal de Administração, Finanças, Planejamento e Orçamento de São Miguel/RN - setor de tributação, existem outros registrados de períodos anteriores e outros ainda que são executados clandestinamente, sem autorização do município, sem licença do Instituto de Desenvolvimento Sustentável e Meio Ambiente (IDEMA) e sem pagamento dos tributos que incidem sobre o uso do solo urbano, que mesmo mediante notificação municipal, continuam seu parcelamento e construção.

Caminhos de Geografia

abr./2021

p. $182-200$

Página 194 
Houve uma profusão, uma coisa sem controle desses loteamentos. [...] Se antes pensávamos que os loteamentos iam surgir muito em função apenas da ampliação da estrutura urbana, dos núcleos já instituídos, não. Hoje a gente percebe loteamentos em toda a área do município (PREFEITO MUNICIPAL DE SÃO MIGUEL/RN, 2018).

Souza; Faria; Stephan (2015) ao estudarem a produção do espaço urbano de uma cidade pequena, apontam que a expansão das cidades nos séculos XX e XXI está associada aos parcelamentos do solo, sejam eles legais ou ilegais, pautados nos interesses imobiliários.

O parcelamento desenfreado que ocorre em São Miguel/RN é alvo da especulação imobiliária e em maior parte, é realizado quando a terra muda de funcionalidade produtiva ou quando o detentor de grandes parcelas falece e estas são rateadas entre os herdeiros, o que é corroborado na fala de alguns entrevistados, representados pela fala do Chefe do Departamento de Fiscalização de Obras do município de São Miguel/RN:

As mudanças foram grandes. Não são poucas. São Miguel tem crescido demais. Em termos de loteamentos, anteriormente os proprietários viam a terra como sobrevivência. Hoje, as pessoas "pegam" essas terras e quando os proprietários atuais chegam a falecer, eles rateiam essas localidades e rapidinho vendem. Não querem nem saber, a qualquer custo querem liberar elas para loteamentos, parcelamentos (CHEFE DO DEPARTAMENTO DE FISCALIZAÇÃO DE OBRAS DO MUNICÍPIO DE SÃO MIGUEL/RN, 2018).

A Moradora do Alto Santa Tereza (2018) também declarou que a extensão de terras de seu pai foi suficiente para produzir quatro quadras das existentes atualmente. Após o seu falecimento, os filhos dividiram a herança da gleba e comercializaram os lotes.

Clementino (1995, p. 24) expressa que a "A cidade é produzida na medida que as formas de propriedades existentes vão se transformando em capital industrial ou comercial". Assim, a mudança da funcionalidade das áreas destinadas aos loteamentos contribui de maneira significativa para a urbanização, já que áreas até mesmo sem ocupação, por serem parceladas e conterem equipamentos característicos de espaço urbano são considerados como tal, o que favorece a valorização imobiliária, objetivo do capital.

Nas pequenas cidades do Rio Grande do Norte, os proprietários de áreas urbanas escolhem parcelar o solo para obter renda proveniente de suas terras, o que contribui para o crescimento da malha urbana citadina (MOURA; COSTA, 2016).

A evolução da implantação de loteamentos mostra a concentração da propriedade privada da terra, que colabora para o processo de especulação fundiária, para o seletivo e restrito acesso à terra e, para a segregação socioespacial devido ao crescimento e a valorização desigual da cidade (SANTOS, 2012).

Nota-se ainda que com a expansão urbana, as delimitações de bairros com suas respectivas nomenclaturas duplicaram quando comparadas com as citadas no Plano Diretor Participativo e indicadas na Figura 3. Em 2008 havia a divisão da área urbana em seis bairros enquanto em 2017 o espaço estava dividido em doze denominações de bairros, como mostra a Figura 4, sendo as novas nomenclaturas: Nossa Senhora de Guadalupe, Núcleo Tenente Adauto, Vista Alegre, Tota Barbosa, José Vicente do Rêgo e Vereador Raimundo Pedro. Este fato está relacionado à oficialização de áreas como pertencentes ao meio urbano por leis de denominação de bairros, sancionadas após a elaboração do Plano Diretor Participativo, além da inclusão de áreas ao perímetro urbano de São Miguel/RN, como é o caso da Vila Cachoeira, Sítio Novo, Sítio Oiteiro e Sítio Estivas dos Paulinos, e da nomenclatura que remete ao meio urbano do Núcleo Vereador Raimundo Pedro (antes Sítio 
Açude). A Tabela 1 contempla as leis de denominação de bairros e de inclusão em inclusão em perímetro urbano no período de 2000 a 2017.

Tabela 1 - Leis de denominação de bairros e inclusão de áreas no perímetro urbano de São Miguel de 2000 a 2017.

\begin{tabular}{|c|c|c|}
\hline Lei № & Data & Descrição \\
\hline $485 / 2002$ & $23 / 12 / 2002$ & Vila dos Sem Terra - Denominada Vila Tôta Barbosa \\
\hline 006/2009 & $19 / 05 / 2009$ & $\begin{array}{c}\text { Cavalo Morto e Sítio Vista Alegre - A nova } \\
\text { nomenclatura é Bairro Vista Alegre }\end{array}$ \\
\hline $007 / 2011$ & $15 / 09 / 2011$ & $\begin{array}{c}\text { Vila Outeiro - Denominação a partir da lei: Bairro Nossa } \\
\text { Senhora de Guadalupe. }\end{array}$ \\
\hline $41 / 2013$ & $18 / 12 / 2013$ & $\begin{array}{c}\text { Vila Cachoeira e Sítio Novo - Inserido no Perímetro } \\
\text { Urbano com a denominação Bairro José Vicente do } \\
\text { Rêgo. }\end{array}$ \\
\hline $42 / 2013$ & $18 / 12 / 2013$ & $\begin{array}{l}\text { Sítio Estiva dos Paulinos - Inserido no Perímetro } \\
\text { Urbano como território do Bairro Núcleo Manoel Vieira }\end{array}$ \\
\hline $43 / 2013$ & $18 / 12 / 2013$ & $\begin{array}{c}\text { Sítio Oiteiro - Inserido no Perímetro Urbano como } \\
\text { território do Bairro Sabino Leite }\end{array}$ \\
\hline $14 / 2014$ & $13 / 10 / 2014$ & $\begin{array}{c}\text { Sítio Açude - Denominado a partir desta lei de Núcleo } \\
\text { Vereador Raimundo Pedro }\end{array}$ \\
\hline
\end{tabular}

Fonte - Secretaria Municipal de Desenvolvimento Urbano de São Miguel/RN (2018).

Apenas uma das leis listadas na Tabela 1 é anterior ao Plano Diretor Participativo: a da denominação da Vila Tôta Barbosa, o que corrobora a expansão urbana significativa de São Miguel/RN a partir do instrumento de ordenamento territorial Plano Diretor Participativo. As leis que descrevem a inclusão no perímetro urbano são três: 41/2013, 42/2013 e 43/2013, referentes à Vila Cachoeira e Sítio Novo, Sítio Estivas dos Paulinos, Sítio Oiteiro, respectivamente. Não foi possível realizar a espacialização dessas áreas inseridas no perímetro urbano porque não há demarcação anexada à lei, sendo determinado apenas que o município tem um prazo de dois anos para realizar o levantamento topográfico, mas que até o momento da conclusão deste estudo este levantamento não havia sido realizado.

A alteração da classificação de área rural em urbana é um negócio com elevada rentabilidade e de grande interesse dos proprietários fundiários e, sua concretização depende da autorização do poder público municipal; a valorização do solo é confirmada quando o preço de venda da área rural é calculado por hectare enquanto o da área urbana tem como unidade de cálculo o metro quadrado (LEONELLI e CAMPOS, 2018).

Destaca-se ainda que a expansão urbana também impacta na arrecadação do IPTU, o que pode ser um dos fatores do interesse público em adotar a conversão das áreas rurais em urbanas. Informações do período de 2003 a 2017 disponíveis no Tribunal de Contas do Estado do RN (2018) - Relatório de Receitas de São Miguel/RN de 2003 a 2011; e na Secretaria Municipal de Administração, Finanças, Planejamento e Orçamento de São Miguel/RN - Setor Tributação (2018) - Baixas Bancárias de 2012 a 2017, mostram a evolução do valor arrecadado de IPTU com maior ênfase a partir de 2007, apontando seu crescimento com a instituição do Plano Diretor Participativo, em 2008, uma vez que o comparativo do valor arrecadado em 2017 com o valor de 2007 resulta em uma diferença de arrecadação de $119,81 \%$.

Portanto, verifica-se que a expansão urbana de São Miguel/RN está associada a várias dinâmicas, que perpassam pela inversão do cenário da população rural e urbana, variações decorrentes da economia, ampliação do sistema viário, modificação da função de utilização da propriedade e da adoção de mecanismos de ordenamento territorial, como o plano diretor participativo. 


\section{CONSIDERAÇÕES FINAIS}

A expansão urbana recente (2000 a 2017) de São Miguel/RN teve a influência de dinâmicas sociodemográficas, do crescimento do setor terciário, dos parcelamentos do solo urbano e dos direcionamentos existentes em legislação municipal, ratificando a produção capitalista do espaço. A alteração da representatividade populacional rural e urbana foi motivada pela busca de serviços, pelas oportunidades de trabalho assalariado e pela "economia sem produção", fatos confirmados a partir da evolução significativa do setor terciário (de 2000 a 2015) e da concessão de benefícios no período de 2000 a 2017 no município de São Miguel/RN.

A expansão territorial urbana de São Miguel/RN ocorreu em uma proporção muito elevada no lapso temporal avaliado neste trabalho e teve como fatores impulsionadores a elaboração do Plano Diretor Participativo do Município no ano de 2008 que ampliou os limites da sede urbana para além das áreas consolidadas; a instauração de leis de conversão de áreas rurais em urbanas, que ultrapassam as áreas delimitadas pelo Plano Diretor Participativo; e a formação de loteamentos, que ocuparam grande parte do território urbano e continuam a estender sua atuação para localidades periféricas da sede urbana do município com a perspectiva de que estas também sejam incluídas na malha urbana e, consequentemente, gerem maiores lucros para seus proprietários.

Dessa forma, os agentes produtores do espaço urbano Município e Proprietários de Terras são os principais responsáveis pela expansão urbana elevada que ocorreu em 17 anos em São Miguel/RN, tendo o capital como força motriz, uma vez que a ampliação do espaço urbano incrementa arrecadação de tributos municipais urbanos e as áreas passam a ser mais valorizadas.

\section{AGRADECIMENTOS}

A primeira autora agradece à CAPES - Código de Financiamento 001 pela bolsa concedida para a realização do curso de Mestrado em Planejamento e Dinâmicas Territoriais no Semiárido (PLANDITES).

\section{REFERÊNCIAS}

ARAÚJO, L. A.; LIMA, J. P. R., Transferências de renda e emprego público na economia do semiárido nordestino. Revista Planejamento e Políticas Pública do IPEA, Brasília, n. 33, p. 45-77, 2009.

ATLAS DO DESENVOLVIMENTO HUMANO BRASIL. 2010. São Miguel/RN. Disponível em: <http://atlasbrasil.org.br/2013/pt/consulta/>. Acesso em: 30 abr. 2020.

BRASIL. Lei 6.766, de 19 de dezembro de 1979. Dispõe sobre o Parcelamento do Solo Urbano e dá outras Providências. Diário Oficial da República Federativa do Brasil.

CLEMENTINO, M. L. M. Economia e urbanização: o Rio Grande do Norte nos 70. Natal: Ed UFRN, 1995.

CORRÊA, R. L. 1989. O Espaço Urbano. São Paulo: Editora Ática, 1989.

COMPANHIA DE PESQUISA DE RECURSOS MINERAIS (CPRM) - Serviço Geológico do Brasil. Projeto cadastro de fontes de abastecimento por água subterrânea. Diagnóstico do município de São Miguel, estado do Rio Grande do Norte. MASCARENHAS, J. C.; BELTRÃO, B. A.; SOUZA JUNIOR, L. C.; PIRES, S. T. M.; ROCHA, D. E. G. A.; CARVALHO, V. G. D. (orgs.). Recife: CPRM/PRODEEM, 2005.

DANTAS, J. R. Q. D.; SILVA, F. S. B. A (RE) ORGANIZAÇÃO SÓCIO-ESPACIAL NO RIO GRANDE DO NORTE E SUAS IMPLICAÇÕES PARA O ALTO OESTE: PARTICULARIDADES SOBRE PAU DOS FERROS. Revista de Desenvolvimento Econômico, Salvador, ano XIII, № 24, 35-44, 2011.

FAHMI, F. Z.; HUDALAH, D.; RAHAYU, P.; WOLTJER, J. Extended urbanization in small and mediumsized cities: The case of Cirebon, Indonesia. Habitat International, v. 42, p. 1-10, 2014. https://doi.org/10.1016/j.habitatint.2013.10.003

FERNANDES, P. H. C. O urbano brasileiro a partir das pequenas cidades. Revista Geoaraguaia, v. 8, n. 1, 2018. https://doi.org/10.35701/rcgs.v21n1.421 
FERNANDES, P. H. C.; CORREIA, S. J. Pequenas cidades, grandes problemas urbanos: a realidade de São Sebastião da Amoreira (PR). VÉRTICES, Campos dos Goytacazes, v. 20, n.1, p. 54-66, 2018. https://doi.org/10.19180/1809-2667.v20n12018p54-66

FONTANELLA, B. J. B.; RICAS, J.; TURATO, E. R. Amostragem por saturação em pesquisas qualitativas em saúde: contribuições teóricas. Cadernos de Saúde Pública, Rio de Janeiro, v. 24, n. 1, p. 17-27, 2008. https://doi.org/10.1590/S0102-311X2008000100003

FURTADO, C. Em busca do novo modelo: Reflexões sobre a crise contemporânea. São Paulo: Paz e Terra, 2002.

HARVEY, D. A Produção Capitalista do Espaço. Tradução: Carlos Szlak. São Paulo: Annablume, 2005. $252 \mathrm{p}$.

HARVEY, D. A liberdade da cidade. In.: VAINER, C.; HARVEY, D.; MARICATO, E.; BRITO, F.; PESCHANSKI, J. A.; MAIOR, J. L. S. et. al. Cidades Rebeldes: Passe livre e as manifestações que tomaram conta do Brasil (p. 47-61 (digital). São Paulo: Boitempo Editorial, 2013.

INSTITUTO BRASILEIRO DE GEOGRAFIA E ESTATÍSTICA (IBGE). 1972. Divisão do Brasil em regiões funcionais urbanas. Rio de Janeiro. Rio de Janeiro. Disponível em: $<$ https://biblioteca.ibge.gov.br/index.php/biblioteca-catalogo?view=detalhes\&id=213622>. Acesso em: 05 abr. 2020.

INSTITUTO BRASILEIRO DE GEOGRAFIA E ESTATÍSTICA (IBGE). 1987. Região de Influência das Cidades. Rio de Janeiro. Disponível em: <https://biblioteca.ibge.gov.br/index.php/bibliotecacatalogo?view=detalhes\&id=219139>. Acesso em: 05 abr. 2020.

INSTITUTO BRASILEIRO DE GEOGRAFIA E ESTATÍSTICA (IBGE). 2000. Região de Influência das Cidades 1993. Rio de Janeiro. Disponível em: <https://biblioteca.ibge.gov.br/index.php/bibliotecacatalogo?view=detalhes\&id=27199>. Acesso em: 05 abr. 2020.

INSTITUTO BRASILEIRO DE GEOGRAFIA E ESTATÍSTICA (IBGE). 2008. Região de Influência das Cidades 2007. Rio de Janeiro. Disponível em: <https://biblioteca.ibge.gov.br/index.php/bibliotecacatalogo?view=detalhes\&id=240677>. Acesso em: 05 abr. 2020.

INSTITUTO BRASILEIRO DE GEOGRAFIA E ESTATÍSTICA (IBGE). 2011. Censo Demográfico 2010 Brasil. Disponível em: <https://cidades.ibge.gov.br/v4/brasil/rn/>. Acesso em: 28 abr. 2020.

INSTITUTO BRASILEIRO DE GEOGRAFIA E ESTATíSTICA (IBGE). 2011. Censo Demográfico 2010 São Miguel. Disponível em: <https://cidades.ibge.gov.br/brasil/rn/saomiguel/pesquisa/23/24007?detalhes=true>. Acesso em: 28 abr. 2020.

INSTITUTO BRASILEIRO DE GEOGRAFIA E ESTATÍSTICA (IBGE). 2011. População residente 2010. Disponível em: <https://sidra.ibge.gov.br/tabela/1378\#resultado>. Acesso em: 28 abr. 2020.

INSTITUTO BRASILEIRO DE GEOGRAFIA E ESTATÍSTICA (IBGE). 2011. População residente, por sexo, situação e localização da área. Disponível em: <https://sidra.ibge.gov.br/Tabela/1309>. Acesso em: 14 abr. 2020.

INSTITUTO BRASILEIRO DE GEOGRAFIA E ESTATíSTICA (IBGE). 2011. População nos Censos Demográficos, segundo as Grandes Regiões e as Unidades da Federação - 1872/2010. Disponível em: <https://censo2010.ibge.gov.br/sinopse/index.php?dados=4\&uf=00>. Acesso em: Acesso em: 24 abr. 2020.

INSTITUTO BRASILEIRO DE GEOGRAFIA E ESTATÍSTICA (IBGE). 2011. Sinopse do censo demográfico 2010. Disponível em: <https://biblioteca.ibge.gov.br/visualizacao/livros/liv49230.pdf>. Acesso em: 30 abr. 2020.

INSTITUTO BRASILEIRO DE GEOGRAFIA E ESTATÍSTICA (IBGE). 2011. Séries Históricas e $\begin{array}{lll}\text { Estatísticas, } & \text { 1940-2010. } & \text { Disponível } \\ \text { <https://seriesestatisticas.ibge.gov.br/series.aspx?vcodigo=POP122>. Acesso em: } 30 \text { abr. } 2020 .\end{array}$

INSTITUTO BRASILEIRO DE GEOGRAFIA E ESTATÍSTICA (IBGE). 2012. Pessoas de 5 anos ou mais de idade que não residiam na Unidade da Federação em 31.07.2005, por lugar de residência em 31/07/2005. Disponível em: <https://sidra.ibge.gov.br/Tabela/3206>. Acesso em: 26 abr. 2020. 
INSTITUTO BRASILEIRO DE GEOGRAFIA E ESTATÍSTICA (IBGE). 2016. Arranjos populacionais e concentrações urbanas no Brasil. $2^{\underline{a}}$ ed. Disponível em: $<$ https://biblioteca.ibge.gov.br/visualizacao/livros/liv99700.pdf>. Acesso em: 30 abr. 2020.

INSTITUTO BRASILEIRO DE GEOGRAFIA E ESTATíSTICA (IBGE). 2017. Produto Interno Bruto dos Municípios. Disponível em: <https:/www.ibge.gov.br/estatisticas-novoportal/economicas/contasnacionais/9088-produto-interno-bruto-dos-municipios.html?=\&t=resultados>. Acesso em: 30 abr. 2020.

LEFEVBRE, H. O Direito à Cidade. Tradução Rubens Eduardo Frias. 5 ed. São Paulo: Centauro, 2001.

LEONELLI, G. C.V; CAMPOS, E. F. R. Leis expansivas para a expansão urbana: Campinas sem limites. Urbe - Revista Brasileira de Gestão Urbana, Curitiba, v. 10 (Supl. 1), p. 36-48, 2018. https://doi.org/10.1590/2175-3369.010.supl1.ao03

MAIA, D. S. Cidades Médias e Pequenas do Nordeste: Conferência de Abertura. In: LOPES, D. M. F.; HENRIQUE, W. (Orgs.) Cidades Médias e Pequenas: Teorias, Conceitos e Estudos de Caso. Salvador: SEI, 2010. p.15-41.

MANFIO, V. O CONTEXTO E A IMPORTÂNCIA DAS PEQUENAS CIDADES NA DINÂMICA DA REDE URBANA: UMA ABORDAGEM ACERCA DE NOVA PALMA, RS. Geoingá: Revista do Programa de PósGraduação em Geografia, Maringá, v. 11, n. 1, p. 24-45, 2019. https://doi.org/10.4025/geoinga.v11i1.49399

MARICATO, E. É a questão urbana, estúpido! In.: VAINER, C.; HARVEY, D.; MARICATO, E.; BRITO, F.; PESCHANSKI, J. A.; MAIOR, J. L. S.; SAKAMOTO, L.; SECCO, L.; IASI, M. L.; NINJA, M.; DAVIS, M.; Movimento Passe Livre; OLIVEIRA, P. R.; ROLNIK, R.; BRAGA, R.; VIANA, S., ŽIŽEK, S.; LIMA, V. A. Lima. Cidades Rebeldes: Passe livre e as manifestações que tomaram conta do Brasil. São Paulo: Boitempo Editorial, 2013. p. 32-46 (digital).

MARICATO, E. Para Entender a Crise Urbana. CaderNAU-Cadernos do Núcleo de Análises Urbanas, Rio Grande do Sul, v. 8, n. 1, 2015, p. 11-22. https://doi.org/10.1590/0103-11042018s315

MARICATO, E.; COLOSSO, P.; COMARÚ, F. A. Um projeto para as cidades brasileiras e o lugar da saúde pública. Saúde em Debate, Rio de Janeiro, v. 42, p. 199-211, 2018.

MEDEIROS, M. S. S. A Produção do Espaço das Pequenas Cidades do Seridó Potiguar. 152 p. Dissertação (Mestrado em Geografia). UFRN: Natal, 2005.

MINISTÉRIO DA FAZENDA. Secretaria de Previdência. 2018. Estatísticas Municipais 2017. Disponível em: <http://www.previdencia.gov.br/dados-abertos/estatisticas-municipais-2017/>. Acesso em: 30 abr. 2020.

MINISTÉRIO DO DESENVOLVIMENTO SOCIAL E COMBATE À FOME. 2004. Política nacional de Assistência Social. Disponível em: <http://www.renipac.org.br/pnas_2004.pdf>. Acesso em: 02 mai. 2020.

MIRANDA, Z. A. I. A incorporação de áreas rurais às cidades: um estudo de caso sobre Campinas, SP. 300 p. Tese (Doutorado em Economia). UNICAMP: Campinas, 2002.

MOURA, F. A.; COSTA, A. A. Cidades $x$ Loteamentos: o mercado de terras nas pequenas cidades do Rio Grande do Norte. Geosaberes, Fortaleza, v. 6, n. especial (3), 506-518, 2016.

NEVES, R. M.; FARIA, T. J. P. O estado da questão da produção acadêmica recente sobre o urbano nas cidades pequenas: análise de teses e dissertação (2009-2018). Geografia Ensino \& Pesquisa, Santa Maria, v. 24, p. 11, 2020. https://doi.org/10.5902/2236499439124

PAGLIARIN, S. Linking processes and patterns: Spatial planning, governance and urban sprawl in the Barcelona and Milan metropolitan regions. Urban Studies, December 2018, v. 55(16), p. 3650-3668, 2018. https://doi.org/10.1177/0042098017743668

SANTOS, M. A urbanização brasileira. São Paulo: Editora da Universidade de São Paulo, 2008.

SANTOS, E. O. Propriedade Privada da Terra e Expansão Urbana: o caso da concentração fundiária na implantação de loteamentos em Fortaleza (1930-2000). Ateliê Geográfico, Goiânia, v. 6, n. 4, 61-87, 2012. https://doi.org/10.5216/ag.v6i4.17026

$\begin{array}{lllll}\text { Caminhos de Geografia } & \text { Uberlândia-MG } & \text { v. 22, n. } 80 & \text { abr./2021 } & \text { p. 182-200 Página } 199\end{array}$


SÃO MIGUEL. Lei 656, de 30 de junho de 2008. Dispõe sobre o Plano Diretor Participativo de São Miguel/RN. Disponível em: <https://www.saomiguel.rn.gov.br/legislacao/leis-municipais>. Acesso em: 27 abr. 2020.

SÃO MIGUEL. 2017. Cronologia Histórico-Política e Administrativa de São Miguel. Cartilha 25 p.

SILVA, S. S. D. B.; BEZERRA, J. A. A EXPANSÃO URBANA DE SÃO MIGUEL (RN): PLANEJAMENTO URBANO E CONFORMIDADES EM UMA CIDADE DE PEQUENO PORTE. ACTA GEOGRÁFICA, Boa Vista, v. 12, n. 30, p. 131-149, 2018.

SOUZA, K. D.; FARIA, T. C. A.; STEPHAN, I. I. C. PROCESSO DE FORMAÇÃO SOCIOESPACIAL DE PEQUENAS CIDADES: o caso de Serro. Oculum Ensaios, Campinas, v. 12 (1), 141-155, 2015. https://doi.org/10.24220/2318-0919v12n1a2718

SPOSITO, E. S.; JURADO DA SILVA, P. F. Cidades Pequenas: Perspectivas Teóricas e Transformações Socioespaciais. Jundiaí: Paco Editorial, 2013.

TERFA, B. K.; CHEN, N.; ZHANG, X.; NIYOGI, D. Urbanization in Small Cities and Their Significant Implications on Landscape Structures: The Case in Ethiopia. Sustainability, v. 12, n. 3, p. 1-19, 2020. https://doi.org/10.3390/su12031235

TRIBUNAL DE CONTAS DO ESTADO DO RIO GRANDE DO NORTE. 2018. Informações do Órgão Jurisdicionado: Prefeitura Municipal de São Miguel. Disponível em: <http://www.tce.rn.gov.br/TransparenciaJurisdicionados/ConsultaOrgaos>. Acesso em: 15 abr. 2020. 